\title{
Seasonal patterns of wind-induced upwelling/downwelling in the Mediterranean Sea*
}

\author{
ANDREW BAKUN ${ }^{1,2}$ and VERA NATALIE AGOSTINI ${ }^{1,3}$ \\ ${ }^{1}$ Marine Resources Service, Fisheries Department, FAO, Rome, Italy. \\ ${ }^{2}$ Lab. Halieutique et Ecosystèmes Aquatiques, Institut de Recherche pour le Développement (IRD), Montpellier, France. \\ E-mail: andrewbakun@hotmail.com \\ ${ }^{3}$ School of Fisheries, University of Washington, Seattle, Washington,USA.
}

\begin{abstract}
SUMMARY: The historical file of wind observations from maritime weather reports is summarized to identify the characteristic seasonal distributions of wind-induced Ekman upwelling and downwelling in the Mediterranean Sea. Both coastal upwelling/downwelling and wind-stress curl-driven "open ocean" upwelling/downwelling are treated in a unified description. Vigorous upwelling zones are found in the eastern Aegean Sea, off the west coast of Greece, and in the Gulf of Lyons. The southern coast of the Mediterranean is found to be primarily a downwelling area, although significant coastal upwelling does appear in the Gulf of Sidra during the spring and summer seasons, and along the Algerian coast during summer.
\end{abstract}

Key words: Mediterranean, upwelling, productivity, wind, COADS.

\section{INTRODUCTION}

The Mediterranean is, on average, an oligotrophic sea. Nevertheless, it supports sizeable and very valuable fisheries, suggesting that the Mediterranean must contain patches of substantial organic production, at least on a fine-scale. Because low dissolved plant nutrient concentrations are believed to be the major reason for the overall oligotrophy, one expects that such patches of elevated productivity should occur where nutrient supply to the upper photosynthetic layers of the sea is significant.

Divergent flow of surface waters driven by the stress of the wind acting on the sea surface is well known to induce upwelling of nutrient-enriched subsurface waters, thereby enhancing nutrient sup-

\footnotetext{
*Received July 28, 2000. Accepted March 9, 2001.
}

ply to the upper layers of the ocean. Because of the convoluted coastline and complex topographic relief of the Mediterranean coastlands, strong spatial patterning of the sea surface wind stress is to be expected. Previous descriptions of the characteristic shapes of these patterns in this region have depended on composite averages of synoptic analyses of distributions of simultaneously observed reports or on model results based on such distributions (Crise and Crispe, 1998). The data-based spatial resolution attained in this manner is limited to the rather coarse spatial distribution of reports available during any synoptic sampling period (i.e., the reports made relatively simultaneously by ships or other observation platforms in the area at any given moment). Any smaller-scale features appearing in distributions so produced will have had to have been generated by various assumptions underlying interpolation func- 
tions used in analysis procedures, or else created by some dynamic forecast model, etc.

Here we take a different approach which permits a higher spatial resolution description of the characteristic long-term mean seasonal cycle of sea surface wind stress patterns (Bakun and Nelson, 1991). The mean seasonal cycle is the component of variability which tends to be of greatest interest to attempts to infer ecosystem processes and function, and tends to be the baseline against which all other scales of variability are evaluated.

\section{Scope and limitations}

In this study, we employ the term upwelling in the sense defined by Smith (1968) in his classic review of the subject, i.e., "an ascending motion, of some minimum duration and extent, by which water from subsurface layers is brought into the surface layer and is removed from the area of upwelling by horizontal flow". Thus, it is not our intention here to treat all of the potential processes (e.g., turbulent mixing, vorticity-induced upwelling, breaking of internal waves, etc.) by which transfers from subsurface layers to surface layers may occur in the sea. Moreover, we are addressing in particular the effect of the wind pattern in inducing either (1) coastal upwelling resulting from the flow divergence that occurs when surface waters are transported offshore from a solid coastal boundary, the driving force being the component of wind stress which is parallel to the coast, or (2) "open ocean upwelling" which occurs as a result of flow divergence induced by spatial variation in the pattern of sea surface wind stress, the driving force in this case being the wind stress curl (Smith 1968). Regions characterized by wind-induced upwelling are known to comprise some of the most productive large-scale oceanic areas in the world (Cushing 1969, Bakun 1996).

According to the definition of upwelling given above, the wind variations of interest are those which are comparable to a half-pendulum day, which corresponds to about one calendar day in the latitude range of the Mediterranean, or longer (i.e., the Ekman transport approximation applies). Shorter period wind oscillations may induce accelerations of surface waters that may tend to largely cancel one another in their net effect on the longer time-scale surface divergence or convergence patterns that determine the patterns of actual upwelling or downwelling, although they may result in net vertical transfers through non-linear processes such as resul- tant turbulent mixing, generation of breaking internal waves, etc. According to our above-cited definition, this class of processes does not constitute upwelling as such, and is not treated in this paper.

\section{METHODS}

The procedure involves compositing together and vector-averaging available reports of wind stress estimates within similar seasonal segments taken from a large number of years. This results in effects of interyear variability (and also random measurement or reporting errors, etc.) being largely "averaged away", leaving an estimate of the underlying characteristic pattern for each seasonal segment. Because of the much larger numbers of actual observations incorporated in this manner, the spatial resolution thereby attained is far greater than could ever be defined in any simultaneous synoptic report distribution. Because the non-linear computations involved in producing the stress estimates are performed on each individual observation prior to any averaging operations, the mean fields reflect undistorted estimates of the long-term stress magnitudes and spatial patterns. The curl is a linear mathematical operator, and so computing the curl on the averaged seasonal distributions likewise introduces no distortion (mathematically, the 'curl of the mean' is identically equal to the 'mean of the curl').

\section{Data}

The data employed were extracted from the Comprehensive Ocean-Atmosphere Data Set (COADS) which is the result of a longstanding international cooperative effort to assemble and computerize the information contained in weather observations made by ships at sea in all regions of the world's oceans (Slutz et al., 1985; Woodruff et al., 1987). The total file contains over 100 million observations dating as far back as 1854 .

A summary file of greatly reduced size in which the observations have been averaged by $2^{\circ}$ latitude $\mathrm{x}$ $2^{\circ}$ longitude quadrangular areas has been made available and has been widely used in ocean climate studies. However, the Mediterranean Sea contains a very high density of maritime reports relative to most other areas of the world's oceans. Also, $2^{\circ} \mathrm{x} 2^{\circ}$ summary areas represent quite a coarse resolution relative to the coastline and topographical features within the Mediterranean. For example, effects of 


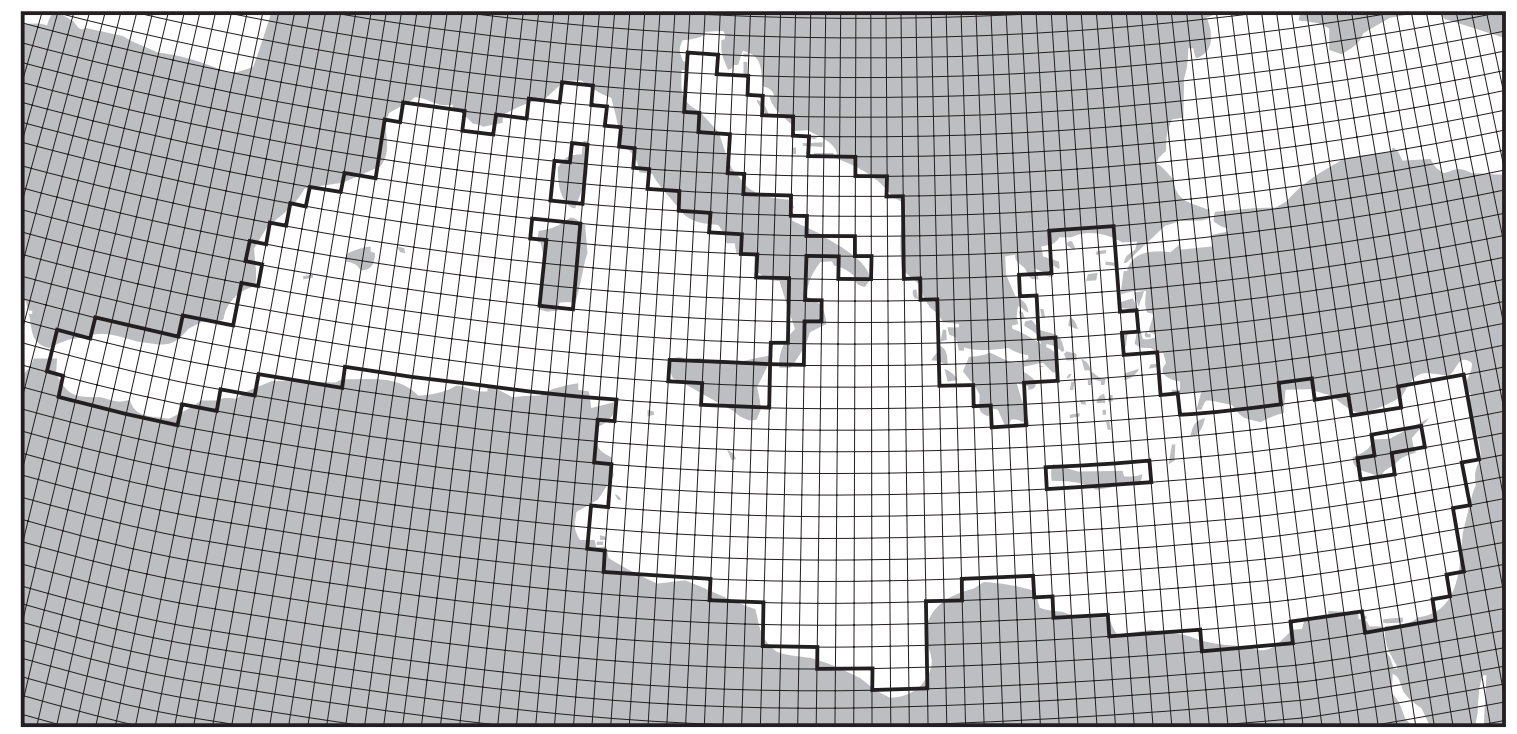

FIG. 1. - Grid of one-half degree lat-long quadrangles used for data summarization. The heavier line separates the grid cells that were selected as being "land" areas, where sea surface wind stress is defined to be zero, and grid cells considered as being "sea" areas where characteristic sea surface wind stress estimates are produced from maritime reports. Thus this heavier line operates as the effective coastal boundary in the wind stress curl and vertical velocity computations.

important coastline indentations or coastal topographic features may be suppressed or lost by summing together with more numerous data taken from large open sea areas. In fact, $2^{\circ} \times 2^{\circ}$ quadrangles are large enough to encompass data from both the Adriatic Sea and Tyrrannean Sea sides of the Italian Peninsula, as well as opposite coasts of major islands such as Crete, Sardinia, Cypress, etc. In the Alboran Sea area, the entire Mediterranean is less than $2^{\circ}$ latitude in width. The widths of the Adriatic and Aegean Seas are also tend to be $2^{\circ}$ or less, as is the distance from the southern coast of Crete to the coast of Libya. Moreover, curl computations involve spatial derivatives, thereby requiring not just one summary area but rather lines of at least two (and optimally three, in order to support central difference derivative formulations) adjacent summary areas arrayed in each coordinate direction and centered about each location for which a curl computation is produced. Obviously, with such an arrangement, data summarized by $2^{\circ} \times 2^{\circ}$ quadrangles could yield curl computations for only a minor fraction of the total area of the Mediterranean Sea.

For these reasons, rather than using the standard $2^{\circ} \times 2^{\circ}$ COADS summaries for this study, we have gone back to the original reports and re-summarized the data on a much finer $0.5^{\circ}$ latitude $\mathrm{x} 0.5^{\circ}$ longitude format (Fig. 1). For this we have used a versatile COADS data file (Roy and Mendelssohn, 1998) assembled and distributed on computer readable CD-ROM by the Climate and Eastern Oceans Sys- tems (CEOS) project (Durand et al., 1998). Many of the reports in the COADS file made before the end of the Second World War contain positions noted only to whole degrees of latitude and longitude. It is generally impossible to differentiate these from reports that were actually reported to tenths of a degree and were truly within one-tenth of the nearest integral whole degree. To prevent undue loss of resolution due to this uncertainty in actual reported position, we have chosen to use only data from the more recent time interval beginning in 1946. A resulting distribution of observations for a sample 2month seasonal segment is shown in Fig. 2.

Software produced in the CEOS Project was used to extract and compute composite mean wind stress estimates for each one-half degree latitudelongitude quadrangle for 2-month segments of the long-term mean seasonal cycle. Based on the resulting data fields, all the various other operations described below were performed, and the results displayed as seasonal maps, using a prototype version of the Environmental Analysis System (EASY) workstation which was made available for this study by its developer, Systems Applications Inc of Redondo Beach, California.

\section{Computation scheme}

Wind stress estimates are computed from individual wind reports according to the bulk aerodynamic formula 


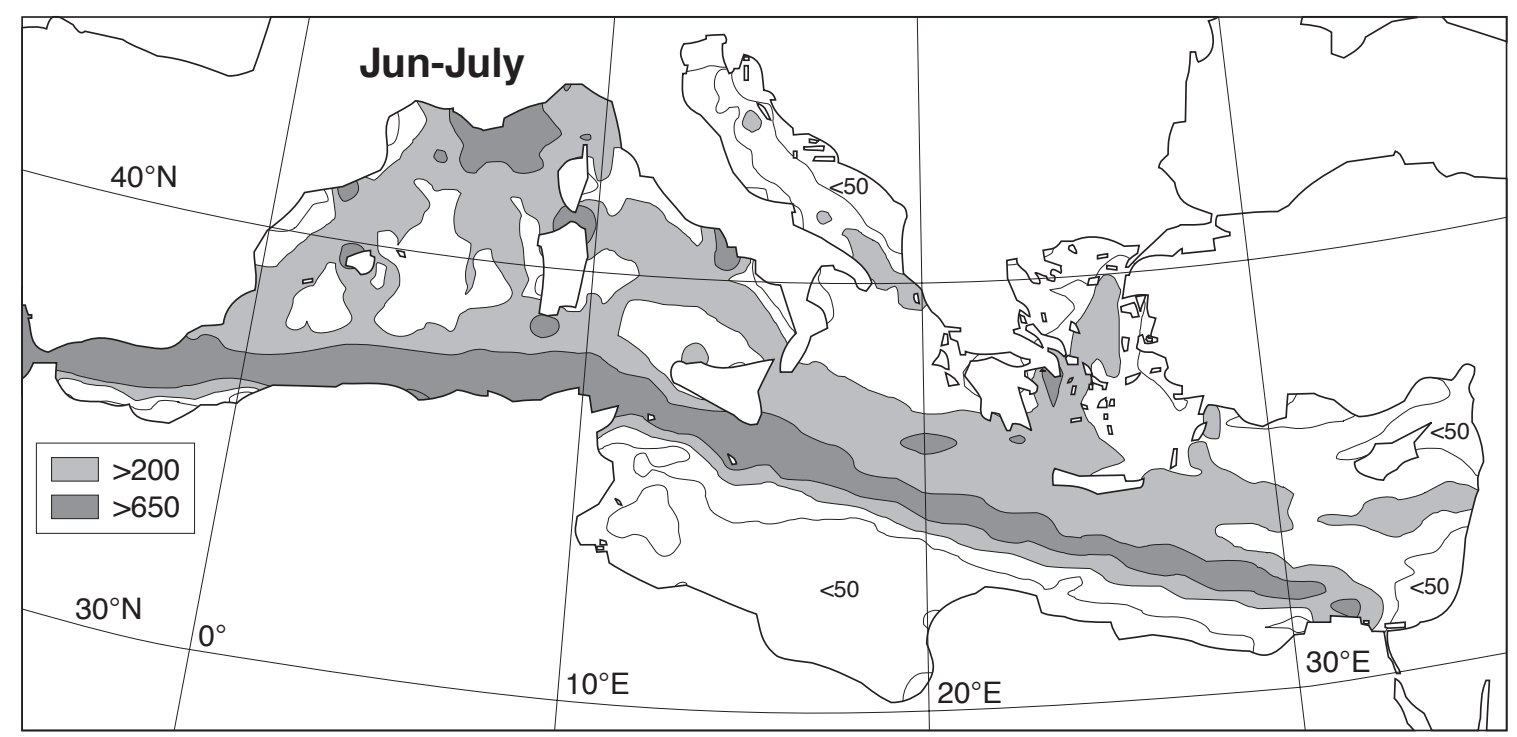

FIG. 2. - Distribution of observations available for one example of the six 2-month long-term composite seasonal samples (Jun-Jul is shown; data from 1946 to latest data in the file).

$$
\underset{\sim}{\tau}=\rho_{a} C_{\mathrm{d}} \mid \underset{\sim}{\mid \mathcal{\nu}} \underset{\sim}{\mathcal{V}}
$$

where $\tau$ is the stress vector, $\rho_{a}$ is the density of air, $C_{\mathrm{d}}$ is a dimensionless drag coefficient, $\underset{\sim}{\mathcal{v}}$ is the wind velocity, and $|\underline{\nu}|$ is the wind speed.

We make reasonable choices for constant values of $\rho\left(0.00122 \mathrm{~g} \mathrm{~cm}^{-3}\right)$ and $C_{\mathrm{d}}(0.0013)$. These are the same values that have been used in a number of other regional upwelling studies that have similarly employed constant drag coefficient formulations Bakun, 1978, 1990; Bakun and Parrish, 1990, 1991; Bakun et al., 1974, 1998; Nelson, 1977; Parrish et al., 1983; Wooster et al., 1976). Since all the subsequent computations represented by Equations 2 to 5 are entirely linear, the results can be simply adjusted by applying appropriate ratios of constant scale factors to make them directly comparable to any other studies based on pseudostress (e.g. Goldenberg and O'Brien, 1981; Servain and Legler, 1986; Breidenbach, 1990) or other constant drag law formulations.

The vertical component of the curl of the wind stress on the sea surface, $\underset{\sim}{\mathrm{k}} \cdot \nabla \times \underset{\sim}{\tau}$ at grid location $(\mathrm{x}, \mathrm{y})$ is calculated in finite (central) difference form as

$$
\underset{\sim}{k} \cdot \nabla \times \underset{\sim}{\tau}=\frac{\tau_{y(x+1)}-\tau_{y(x-1)}}{2 \Delta x}-\frac{\tau_{x(y+1)}-\tau_{x(y-1)}}{2 \Delta y}
$$

where $\tau_{y(x+1)}$ and $\tau_{y(x-1)}$ represent the northward stress components one grid location to the east and one grid location to the west respectively, $\tau_{x(y+1)}$ and $\tau_{y(x-1)}$ represent the eastward stress components one grid location to the north and one grid location to the south respectively, and $\Delta \mathrm{x}$ and $\Delta \mathrm{y}$ are the respective grid mesh lengths in the zonal and meridional coordinate directions (linear distances corresponding to $0.5^{\circ}$ lat and long respectively).

The principle of conservation of mass in a relatively incompressible fluid such as sea water is expressed in the equation of continuity. Since we are interested in the directly wind-driven component of flow we integrate the continuity equation from a depth, $\mathrm{z}=-\delta$, where this component becomes very small in a relative sense (we refer to this depth as the bottom of the Ekman layer) to that at the sea surface. Applying the boundary condition of no flow through the sea surface yields (in finite difference form analogous to Eq. 2)

$$
\mathrm{W}(-\delta)=\frac{\mathrm{U}_{(x+1)}-\mathrm{U}_{(x-1)}}{2 \Delta x}-\frac{\mathrm{U}_{(y+1)}-\mathrm{U}_{(y-1)}}{2 \Delta y}
$$

Since we are addressing time scales of variation which are long compared to the Ekman response time (which is a half-pendulum day or roughly one calendar day in the latitude band of the Mediterranean Sea), we may make use of the Ekman approximation (Ekman, 1905)

$$
\mathrm{V}=-\frac{\tau_{x}}{\rho f} ; \mathrm{U}=-\frac{\tau_{y}}{\rho f}
$$

for computing the actual water transport responding to the applied wind stress (the symbol $f$ representing the Coriolis parameter and $\rho$ signifying the density of water). Substituting expressions (4) into Eq. 3 yields the basic equation 
$\frac{1}{\rho f} w(-\delta)=\frac{\tau_{y(x+1)}-\tau_{y(x-1)}}{2 \Delta x}-\frac{\tau_{x(y+1)}-\tau_{x(y-1)}}{2 \Delta y}$

by which we calculate the vertical velocities at the base of the Ekman layer from a central-difference "curl" calculation based on the composite seasonal wind stress estimates arranged on the grid system displayed in Figure1.

\section{The coastal boundary condition}

The coastal boundary condition requires that there be no flow through the solid coastal boundary. Comparing Equations 3 and 5 term by term makes it clear that the coastal boundary condition of no ocean flow into or out of continental landmass areas is appropriately imposed if one simply ensures that the sea surface wind stress estimates at all grid points located on solid land are set equal to zero (i.e., no sea surface wind stress where there is no sea surface). With the data gridded in this manner one can simply apply Equation 5 at all grid locations located over the sea itself, as definable by the $0.5^{\circ}$ grid resolution (Fig. 1), to yield the composite effect of both the alongshore stress-driven coastal upwelling and wind stress curl-driven open ocean upwelling within the same consistent computation scheme.

This offshore scale is large compared to the expected width of the actual coastal upwelling response, which has a scale width given by the Rossby radius of deformation (Yoshida, 1967; Mooers and Allen, 1971). Computed estimates of Rossby radius values for temperate latitudes generally do not exceed several tens of $\mathrm{km}$, although the continental shelf width may provide an additional offshore scale for coastal upwelling. The pertinent consideration for the results reported here is that the vertical velocity values at the near-coastal grid points do not reflect the real maximum values, but rather an estimate of those values averaged over an offshore scale of about $100 \mathrm{~km}$. This is considered entirely appropriate due to the fact that the 0.5 degree mesh-length of the grid system used to summarize the observed data certainly does not resolve coastal features well enough to support any finer degree of definition. In any case, it represents a large advance in spatial detail over what has been previously definable in terms of a consistent basin-wide picture of the seasonal wind-induced upwelling and downwelling structure of the Mediterranean Sea.

In summary, if one imposes the condition that the stress at grid locations which are located over land be always equal to zero, one can simply apply eq. (5) at all grid locations located over the sea to yield the composite vertical velocity resulting from both the alongshore stress-driven coastal upwelling (or downwelling) and wind stress curl-driven open ocean upwelling (or downwelling, on a spatial scale of the order of two grid mesh lengths. Thus the computed vertical velocities within about $100 \mathrm{~km}$ of the coast will validly represent the net effect of both processes averaged over this spatial scale.

\section{Choices made in defining effective coastal boundaries}

Pooling the observational data over half-degree latitude-longitude areas results in a limitation of the effective resolution of coastline features to the same half-degree latitude-longitude scale (i.e., one has to make a choice whether any particular half-degree quadrangle should represent an area of sea or an area of land). These choices inevitably determine some aspects of the smallest scale spatial details revealed by the analysis. Clearly, one wishes neither to overly exaggerate nor to unduly mask effects of coastline features that are not precisely definable by boundaries of half-degree grid "squares". The choices made for coastline definition for this study are indicated in Figure 1.

Islands represent an interesting problem. The classic Ekman coastal upwelling conceptual model (Sverdrup, 1938) assumes a very long straight coastline such that most of the water that feeds the offshore transport must not flow into the area horizontally, but must come vertically from depth. Obviously, for the coastline of an island to offer a good approximation to this situation, the island must be very large. For a relatively small island lying in the path of a large scale wind flow of a time scale of a half-pendulum day or more, there will be Ekman transport of surface water toward the left side of the island (looking downwind) and away from the right side of the island. (The northern hemisphere orientation is described here; in the southern hemisphere, where the Ekman transport orientation to the wind is reversed, the sides of the islands as cited in this discussion would be reversed). Thus there is a potential driving force for downwelling on the left side of the island and for upwelling on the right side of the island. If the island is small enough, the water accumulating on one side can simply flow around the island in response to the resulting alongshore pressure gradient to replenish the loss of water on the 
other side. For larger islands where quasi-geostrophic dynamics operate, coastal trapped waves (Gill and Clarke, 1974; Allen, 1975) accomplish much the same thing, propagating their entrained velocity fields around the island to create an alongshore flow from the side of the island where the Ekman flow is accumulating surface water to the side where it is carrying it away from the coast. Clearly there will be an interdependence of time scales and space scales such that progressively larger islands will support progressively longer time-scale episodes of coastal upwelling or downwelling.
In this study, we take a quite pragmatic, empirical approach to deciding how to deal with islands in this respect. Satellite images of the largest islands in the Mediterranean -Sicily, Sardinia, Corsica, Crete and Cypress- often exhibit sea surface temperature signatures indicative of coastal upwelling. Thus we chose to represent these as significant coastline features in our computations (Fig. 1). For Mallorca and smaller islands, we found these signatures to be less evident. (In the case of Mallorca, in particular, the island was also particularly hard to portray appropriately by any
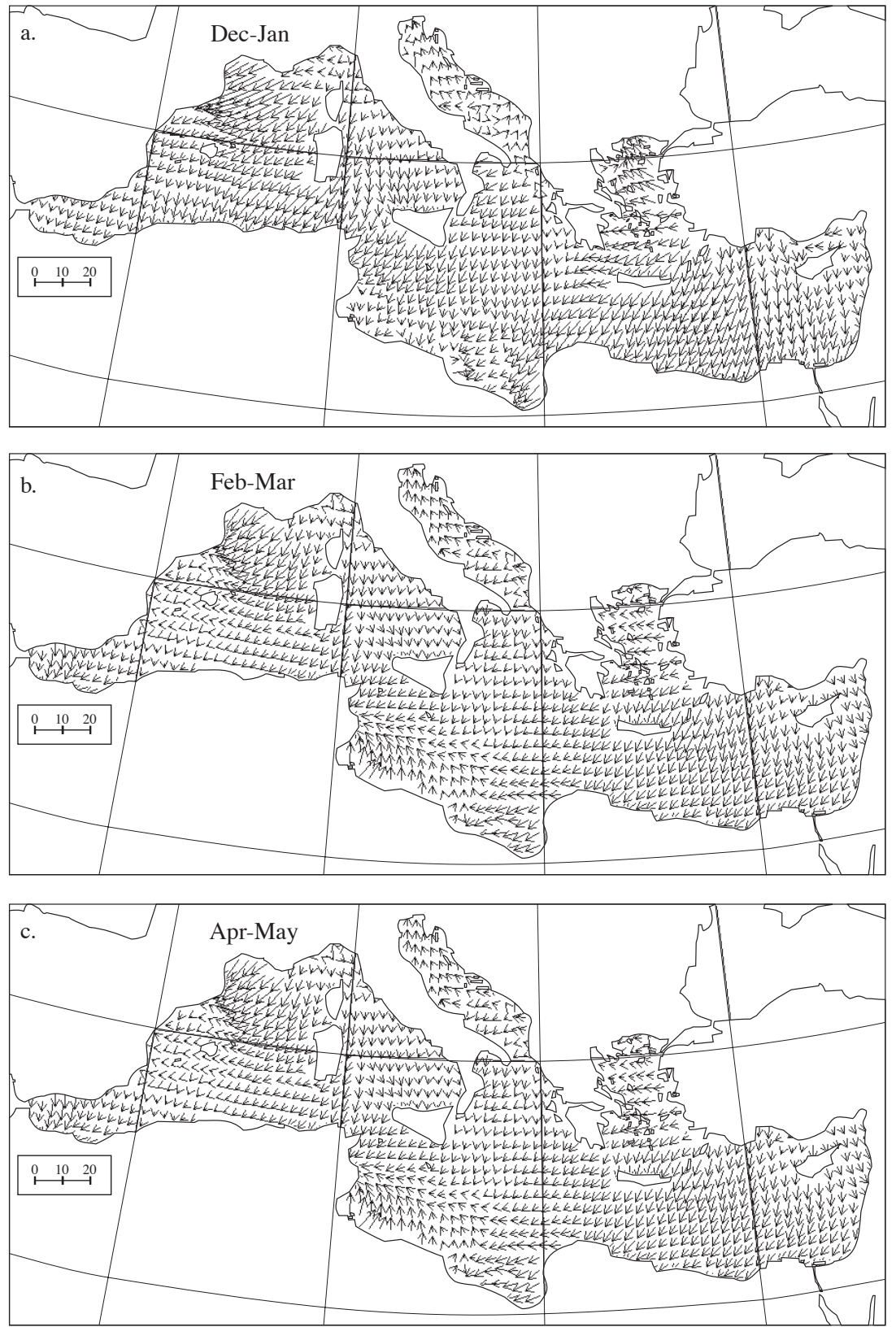

FIG. 3. - Seasonal variation of Ekman transport produced from smoothed distributions of wind stress estimates. Transport magnitudes $\left(\mathrm{t} \mathrm{s}^{-1} \mathrm{~m}^{-1}\right)$ are indicated by length of the vector symbols (reference scale appears on each panel). (a) Dec-Jan. (b) Feb-Mar. (c) Apr-May. (d) Jun-Jul. (e) Aug-Sep. (f) Oct-Nov. 
available choice of grid-cell combinations in our half-degree computation grid.) Consequently, coastal boundary effects of islands the size of Mallorca and smaller are absent from our computed distributions of vertical velocity (Fig. 4). Readers wishing to gauge the seasonal distributions of Ekman convergence and divergence at the coasts of these smaller islands (which could possibly be reflected to some degree in corresponding vertical transfers) will need to make reference to the smoothed Ekman transport vector symbols themselves (Fig. 3).
However, it should be noted that effects on the wind stress curl pattern that may be due to sheltering and wind-channeling effects of islands may induce the "open ocean" type of upwelling. If such effects are of sufficiently large scale, they should indeed be reflected in the computed results presented. But as discussed in Section 1.1, other potential "island effects" which are not directly forced by wind (e.g., upwelling occurring within eddy structures produced by the interaction of current flows with obstructing islands (Aristegui et al. 1997)) are not addressed in this study.
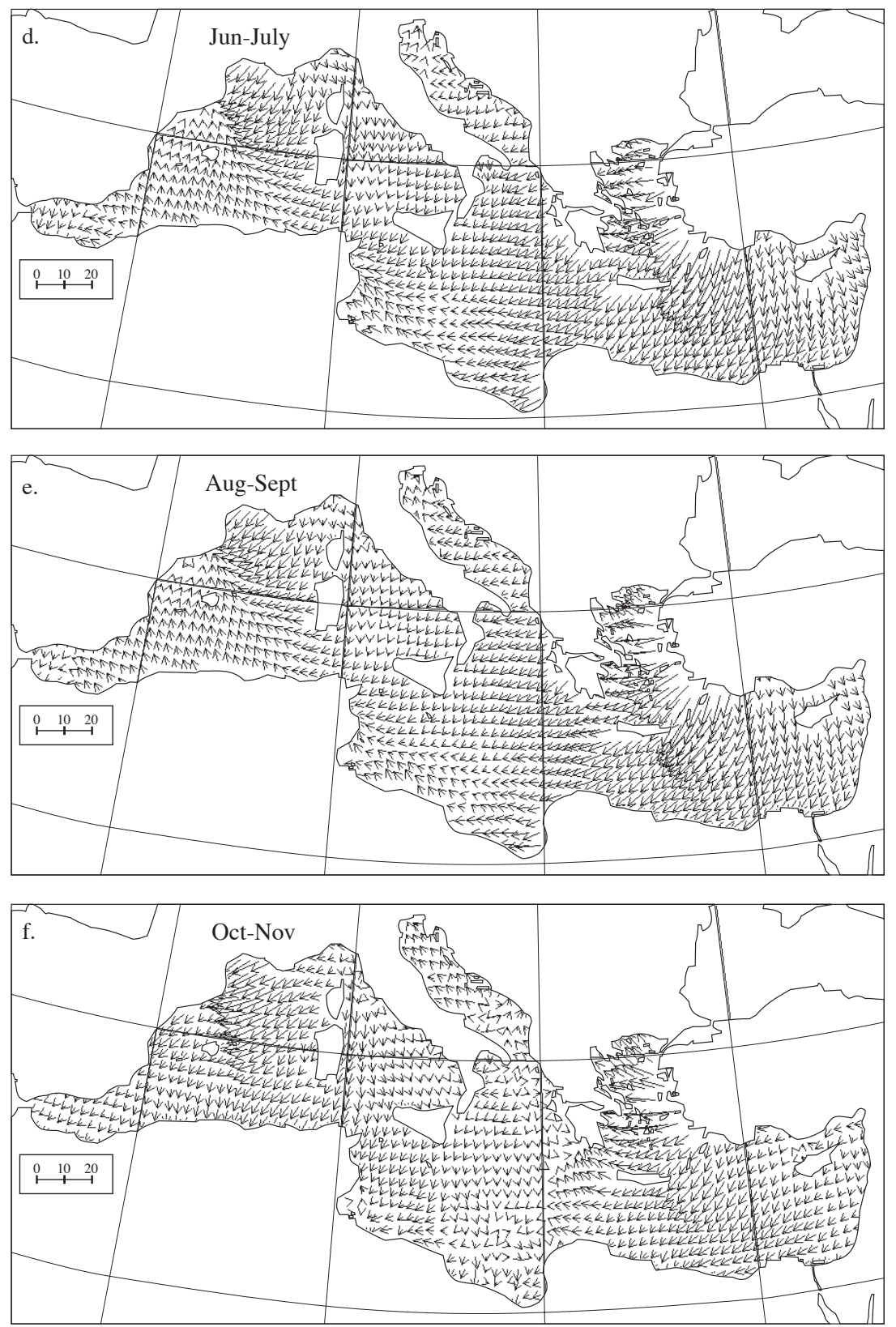

FIG. 3. (Cont.) - Seasonal variation of Ekman transport produced from smoothed distributions of wind stress estimates. Transport magnitudes $\left(\mathrm{t} \mathrm{s}^{-1} \mathrm{~m}^{-1}\right)$ are indicated by length of the vector symbols (reference scale appears on each panel). (a) Dec-Jan. (b) Feb-Mar. (c) Apr-May. (d) Jun-Jul. (e) Aug-Sep. (f) Oct-Nov. 


\section{Smoothing and filling data gaps}

Although the observational data available in the COADS data base for the Mediterranean is rather large in total amount, it is quite unevenly distributed. There are large zones, e.g., along the main ship route between the Straits of Gibraltar and the Suez Canal, much of the Gulf of Lyons, etc., containing at least several hundred observations per half-degree quadrangle for each 2-month seasonal segment (Fig. 2). However, there are other areas, e.g., along the African coast, in the upper extremes of the Adriatic and Aegean Seas, etc., where data are exceedingly sparse, and in fact occasionally entirely lacking for a given grid cell and 2-month seasonal segment. Obviously, some means of filling data gaps is needed.

Even in the cases where data exist, one needs a significant number of observations to arrive at an adequately stable seasonal mean of vector wind stress components, the computed values of which are extremely sensitive to variations both in wind direction and in wind speed (the effects of which are amplified by the process of raising the observed magnitude to the second power; ref. Eq. 1). Sampling error in the curl calculation (Eq. 5) is further amplified by the process of subtracting the mean component values for adjacent samples one from another. Such sampling errors in the calculated wind stress curl values tend to grow rapidly as observations per grid cell sample fall significantly below about one hundred (Bakun and Nelson, 1991), causing very disordered artificial spatial pattern to appear in resulting distributions.

To help ameliorate these problems, a combination of linear and nonlinear spatial smoothing was applied to the distributions of the two vector components of wind stress. This was performed as follows. First, a $1.5^{\circ}$ lat x $1.5^{\circ}$ long areal smoothing filter, covering a total of nine grid cells, arranged in a $3 \times 3$ square array was centered on the half-degree grid cell for which a smoothed value is to be constructed. The nonlinear part of the filter process, designed to guard against potentially serious distortions due to highly non-characteristic values appearing in one or two of the nine component cells of the filter, consisted of trimming and discarding the two highest and two lowest values among the nine data values found in the array. The linear part of the process consisted in computing the average of the values in the remaining five cells. This averaged value is then saved as the new "smoothed" value for the grid cell location at the center of the filter. The filter was applied cell by cell, for each of the two (northward and eastward) wind stress components, producing a new gridded field of smoothed values for each of the wind stress components.

However, when filtering cells adjacent to the coast the $3 \times 3$ grid cell filter encounters cells which have been designated as representing land. These areas, if in reality they contain some actual areas of sea surface, may contain a certain amount of reported data. However, these valid data values would be sparse in any case relative to the much better data density and consequent much greater reliability of the estimates in the adjacent "sea" cells. Moreover, there is a strong possibility that such cells may contain a large percentage of mis-reported data. (For example, an area of high data density in another hemisphere may contain reports in which the hemisphere code is entered incorrectly, causing the maritime reports to erroneously appear over land. Thus reports from the heavily trafficked route through the Straits of Gibraltar which were erroneously coded as "east latitude" instead of "west latitude" would appear as reports on the Algerian coast land). Consequently we have chosen to delete such "land" cells from the filter area in which they fall. Then, the trimming procedure is performed as before and the resulting reduced number of remaining cells averaged. (Thus if four cells were removed from the filter as being "land area" cells, five cells would remain. Of these, four would be trimmed. This would leave one remaining cell. The value of that cell, i.e., the median of the values in the five "sea" cells, would become the smoothed value at the location over which the filter was centered.) There are several places where a "sea" cell is largely enclosed such that the filter area centered on it may contain only four or even three "sea" cells. In these cases, we reduced the nonlinear part of the filter to trim only the single highest and lowest extreme values. In the case of a "four sea cell" situation, this leaves values which are then averaged to produce the relevant smoothed value. There is only one "three sea cell" situation that occurs in the grided system (Fig. 1; i.e., the grid cell in the northwestern Aegean Sea that extends into the bay containing the harbor of Thessalonika). In this case the smoothed value is represented by the median of the three "sea" cells underlying the filter when it is centered at that location.

\section{Significance of indicated features}

Obviously, the finest level of spatial detail definable by the $0.5^{\circ} \times 0.5^{\circ}$ data summaries will 
have been attenuated by the smoothing process which was deemed necessary to suppress the gross sampling error variance and associated high noise level in the computed upwelling/downwelling distributions which would have made interpretation quite difficult and tedious. However, at distances greater than about one grid mesh length from the coast, where the patterning effects of coastal topography have become diffused, one expects that this relatively fine scale would exhibit a lower level of real signal relative to noise introduced by sampling errors.

Directly adjacent to the coast, however, the situation might be different. By smoothing the larger scale wind stress field, one loses the finest scale of spatial variation in the wind available in the onehalf degree lat-long summaries. However, the effect of coastline variation, as well as can be resolved on the one-half degree scale (Fig. 1), is indeed reflected in the vertical velocity estimates (shown in Fig. 4).,

Recall that the central difference derivatives used in the curl calculation (Eq. 5) span two $0.5^{\circ}$ grid mesh lengths. Also, the smoothing filter used may cause data to be incorporated from an additional $0.75^{\circ}$ distance on each end of that span. Thus the maximum possible length scale for any spatial interdependence imposed by our computation, smoothing, and analysis procedures is $2.5^{\circ}$. Consequently, features that exhibit unity and coherence on scales larger than a $2.5^{\circ}$ linear scale can be assigned a high degree of confidence. In addition, the separate twomonth seasonal segments displayed in each of the adjacent panels of Figure 3 and of Figure 4 are based on entirely separate, independent data sets. Thus, it is reasonable to assign an enhanced degree of confidence to features that remain evident, and are stable or exhibit a regular seasonal progression, between adjacent seasonal segments. The discussion to follow focuses on features that conform to both, or at least to the first, of these criteria.

\section{RESULTS}

The Mediterranean Sea lies on the eastern flank of the major subtropical high pressure system of the North Atlantic Ocean, the Bermuda-Azores High. The interaction of this high pressure system with the seasonal continental pressure systems of the great land masses situated to the south, east, and north of the Mediterranean, and with the Icelandic Low which during the winter half of the year extends its influence over much of western Europe, determines the major large scale aspects of the air-flow over the Mediterranean zone. Over the western part, the isobars around the Bermuda-Azores High system generally trend north - south throughout the year. Near the earth's surface, the imbedded meridional geostrophic wind flow tends to be deflected somewhat to the left by frictional effects, and so the sea surface stress has a generally southeastward tendency in this area.

In winter, a weak thermal low pressure zone forms over the relatively warm waters of the Mediterranean. This interacts with a slight ridge of relatively high pressure that forms in winter over the northernmost edge of the African continental land mass, resulting in generally eastward wind stress, and corresponding southward (onshore) Ekman transport (Fig. 3a) in the central and eastern portions of the Sea. The effect of the enormous Asian winter continental high pressure system is reflected in the tendency for westward wind flow (northward Ekman transport) during winter in the extreme northeastern area.

In summer, there is quite a continuous zonal gradient of pressure between the seasonally strengthened Bermuda-Azores High and the intense low pressures of the Asian summer monsoon. This results in a generally southward geostropic wind flow, that near the sea surface is turned by friction and local topographic effects to range from southward (westward Ekman transport) to eastward (southward Ekman transport) over much of the Mediterranean zone. However, in the western half near the African coast, low pressure related to heating of the continental surface turns the coastwise wind flow toward the west, yielding northward, offshore directed Ekman transport.

These large scale features are reflected in the gross distributions of resulting wind-induced upwelling and downwelling in the Mediterranean (Fig. 4): (1) downwelling along the southern coastal boundary during winter, reversing to coastal upwelling off Libya in spring and off Algeria in summer and fall; (2) strong upwelling in the eastern Aegean Sea throughout the year, becoming remarkably intense in the summer and fall seasons; (3) strong summer and fall upwelling in the eastern Ionian Sea; (4) strong upwelling in the Gulf of Lyons; and (5) a tendency for upwelling on the western and/or southern sides of the major islands and downwelling on the northern and/or eastern sides. 

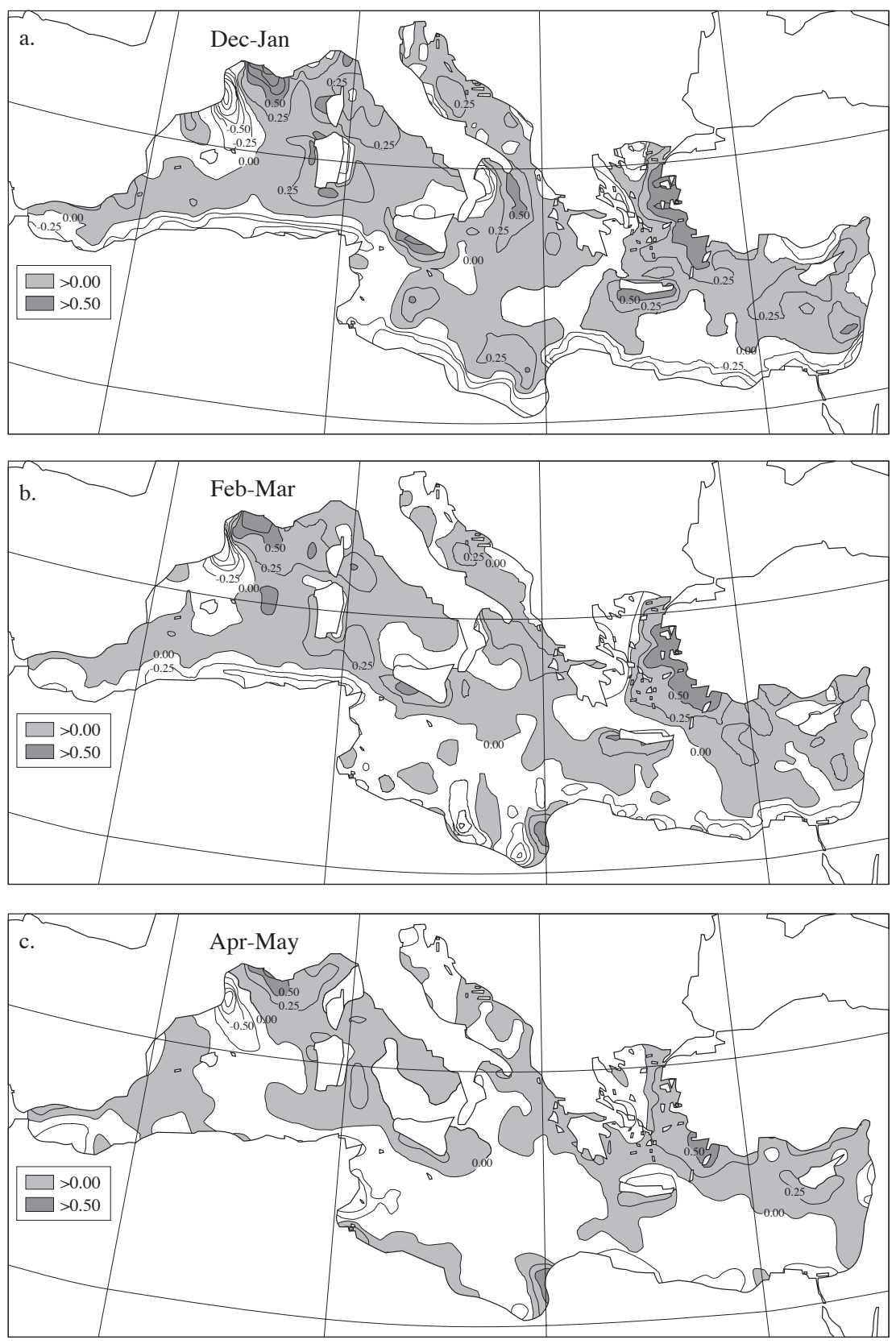

FIG. 4. - Seasonal variation of computed vertical velocities at the bottom of the surface Ekman layer. Units are meters per day. Contour interval is 0.25 . Shaded areas indicate zones of upwelling. Darker shading indicates upward velocities greater than $0.5 \mathrm{~m} / \mathrm{day}$. Unshaded areas indicate zones of downwelling. (a) Dec-Jan. (b) Feb-Mar. (c) Apr-May. (d) Jun-Jul. (e) Aug-Sep. (f) Oct-Nov.

\section{The Alboran Sea and adjacent area}

The predominantly westerly winds in the Alboran Sea tend to induce coastward surface Ekman transport and corresponding upwelling on the Spanish side and offshore-directed transport and downwelling on the African side of this area of the Mediterranean. However, during late summer and fall, the tendency reverses in the area to the east, yielding offshore-directed wind-driven Ekman transport (Fig. 3d,e) and resulting upwelling (Fig. $4 \mathrm{~d}, \mathrm{e})$ along the Algerian coast and onshore tranport and downwelling off southeastern Spain (from Costa de la Luz to Costa Blanca). A clockwise turning tendency in the wind pattern off northern Morocco in summer produces an area of anticyclonic wind stress curl, resulting in convergent surface Ekman flow and corresponding open ocean downwelling over the west central portion of the Alboran Sea. 

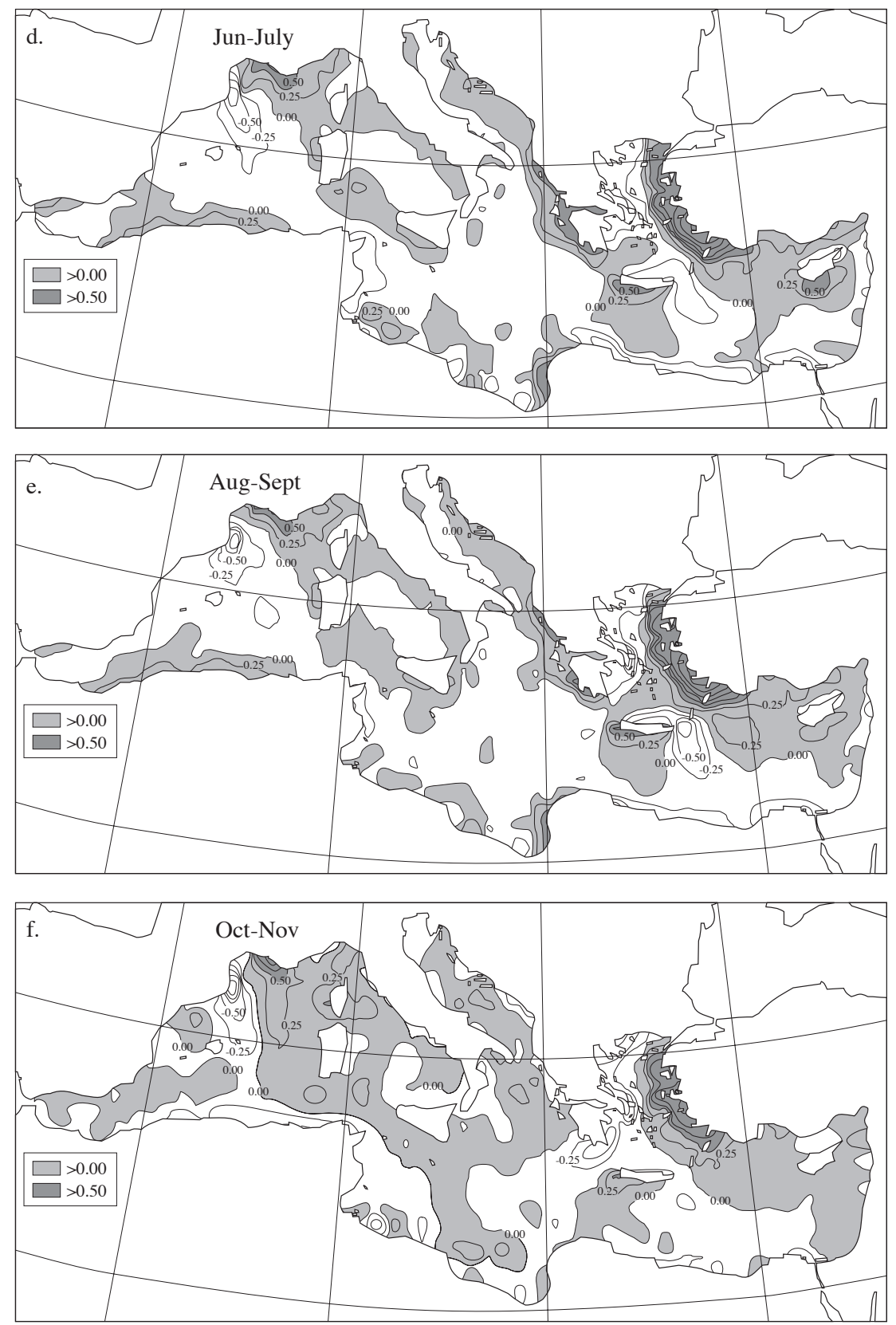

FIG. 4. (Cont.) - Seasonal variation of computed vertical velocities at the bottom of the surface Ekman layer. Units are meters per day. Contour interval is 0.25 . Shaded areas indicate zones of upwelling. Darker shading indicates upward velocities greater than $0.5 \mathrm{~m} / \mathrm{day}$. Unshaded areas indicate zones of downwelling. (a) Dec-Jan. (b) Feb-Mar. (c) Apr-May. (d) Jun-Jul. (e) Aug-Sep. (f) Oct-Nov.

\section{The Balearic Sea}

The Balearic Sea is characterized by a wind pattern favorable to convergent ocean surface transport and downwelling. However this pattern is broken during late fall and winter where strong downslope winds developed in the valley of the Ebro River extend outward over the Sea in a strong offshoredirected wind jet. The resulting zone of strong cyclonic (positive) wind stress curl exerted on the zone of sea surface located to the left of the jet axis produces an area of Ekman divergence and associated upwelling.

As discussed above (see the subsection on coastal boundary condition in the Methods section), we have elected not to include the specific boundary effects of Mallorca or the other islands in the group in our vertical velocity computions. However, the wind field associated with the Ebro jet extends to the vicinity of the islands where significant winter 
wind-driven Ekman transport (Fig. 3a,b,f) is indicated toward the northeastern coasts of the islands and away from their southwestern coasts.

\section{The Gulf of Lyons}

An even stronger analog to the Ebro jet is the jet which exists to the north side of the Pyrénnées mountain range, where a major topographic gap exists between the mountains of the Pyrénnées and the French Massif Central groups. From this gap a deep valley slopes down to the Mediterranean coast, in which air cooled at higher altitudes tends to cascade downward displacing the warmer, less dense, surface air mass. The extension of this "Tramontagne" wind jet out over the Gulf of Lyons acts in conjunction with the similar "Mistral" wind jet produced in the valley of the Rhone River to produce one of the most remarkable features of our computed vertical velocity distributions. Strong zones of intense Ekman divergence and convergence exist on the respective cyclonic (left) and anticyclonic (right) sides of the jet axis. The divergent zone extends to the northern coast of the Gulf, producing an intense upwelling zone from Montpellier to Toulon along the stretch of coast which includes the Rhone Delta and the port of Marseille. The divergent zone, in turn extends southeastward over the sea to beyond the Balearic Islands and southwestward along the Spanish coast to Barcelona. The coupled feature is very strong on average throughout the year but reaches maximum intensity in winter (Fig. 4a), with indicated seasonal average upward velocities at the bottom of the Ekman layer surpassing a meter per day near the coast in the northeastern part of the Gulf, with downwelling velocities of even greater magnitude being indicated near the coast in the southwestern part.

\section{The Ligurian Sea}

The coastal upwelling feature associated with the Tramontagne-Mistral wind pattern actually extends around Cap Coisette and continues along the Côte d'Azur. Here it increases in intensity during the summer months (Fig. 4d) when the predominently offshore-directed wind veers toward the east to yield a larger stress component parallel to the coastline. Offshore, the Ligurian Gulf is an area of largely divergent wind-driven surface flow except for an area of convergence extending northwest from the Island of Corsica.

\section{The Tyrrhenian Sea}

Most parts of the west coast of Italy south of the island of Elba, except in the extreme southwest, are under the influence of winds that on average produce a mild net coastal upwelling tendency. An area of moderate wind driven surface flow divergence, and corresponding mild open sea upwelling, extends out from the part of this coastal upwelling zone which is north of the vicinity of Rome to intersect the southern half of the west coast of Corsica.

South of Rome, the tendency in the offshore area is for mild surface convergence which becomes more intense with proximity to Sicily. The north coast of Sicily contains a zone of relatively intense downwelling which, during the spring and summer (Fig. $4 \mathrm{c}, \mathrm{d}, \mathrm{e})$, develops a moderately intense extension to the northwest that reaches to the west coast of Sardinia, which is a zone of coastal downwelling throughout the year. However, between the western point of Sicily and the southern part of Sardinia there tends to be a zone of substantial wind-induced surface flow divergence and resulting Ekman upwelling.

\section{The Adriatic Sea}

The Adriatic Sea appears to be an area of rather weak average net wind stress, which tends to have a degree of clockwise tendency resulting in weak coastal upwelling on the Balkan side, weak to moderately strong coastal downwelling on the Italian side, and zones of moderate upward Ekman pumping in the interior.

\section{The Ionian Sea}

During the winter, a southwestward wind jet develops in the Gulf of Taranto. On the eastern (cyclonic) side of the jet an area of divergence extends at least $200 \mathrm{~km}$ southward from the "heel" of the Italian "boot". On the western (anticyclonic) side of the jet, a zone of convergence and coastal downwelling occupies the area adjacent to the south coast of Calabria.

In spring, this feature fades. The interior of the Ionian Sea becomes largely convergent but coastal upwelling begins to spread along the west coast of Greece. In summer (Fig. 4d,e), a band of strong upwelling (reaching intensities greater than $0.5 \mathrm{~m}$ day $^{-1}$ off the west coast of the Pelopinnisos) extends along the west coast of Greece. 


\section{The Aegean Sea}

The Aegean sea is characterized by strong northerly (southward) wind stress and correspondingly intense westward Ekman transport (Fig. 3). The resulting Ekman flow away from the coast on the eastern side and toward the coast on the western side produces a upwelling/downwelling couple that is weakest in the spring (Fig. 4c). However, it strengthens rapidly in the late spring and early summer (Fig. 4d) to reach characteristic vertical velocities of 0.5 to $1.5 \mathrm{~m} \mathrm{day}^{-1}$ in a band along the eastern boundary of the Aegean and beyond.

The same wind pattern produces, during the spring, summer and fall seasons, strong coastward transport (Figs. 3d,e) and associated downwelling (Fig. 4d,e) off the northeastern "corner" of the island of. Crete.

\section{The Levantine Sea}

As these northerly winds exit the confines of the Aegean, they undergo a general turning toward the east. As a result, the strong upwelling band along the east side of the Aegean actually curves around the "corner" of the Asia Minor peninsula to produce coastal divergence and upwelling off the southern coast of Turkey. However, north of the island of Cypress this pattern is broken during the winter by the effect of a lobe of the Asian winter monsoon high pressure system which impinges on that stretch of coast and induces an easterly (westward) wind flow and corresponding surface Ekman transport toward the coast (not shown well in Fig. 3 due to vector symbols that would extend across the coastline being obscured) and resulting coastal downwelling (Fig. 4a).

In essentially all seasons, the channel between Cypress and the continental coast is dominated by convergent surface Ekman flow. Coastal divergence that would tend to induce upwelling, occurs on the southern side of the island and is strongest in summer (Fig. 4d).

Along the eastern boundary of the Levantine Sea, the wind stress is generally eastward, toward the coast. Slight turnings of the vectors produce spots of either divergence or convergence; the coastal indentation formed by the coasts of Syria and Lebanon is generally a site of convergence.

The south coast of the Levantine Sea tends to be an area of coastal convergence and downwelling thoughout the year, but is most intense in winter (Fig. 4a).

\section{Gulf of Sidra - Gulf of Gabes}

The wide indentation of the continental coastlines of Libya and Tunisia formed between the Gulf of Sidra (Sirte) and the Gulf of Gabes is an area of extremely low data density. Thus the indications we can draw are very uncertain. It seems generally to be an area of coastward Ekman transport and downwelling. However, during spring and summer the wind tendency appears to turn more northerly (southward) so that the stress becomes parallel to the coastline tending to favor upwelling along the east boundary of the Gulf of Sidra (Fig. 4c,d,e).

\section{Algerian coast}

The Algerian coast, like the rest of the African coast of the Mediterranean, is an area of coastal downwelling during the winter season (Fig. 4a). However, during summer (Fig. 4d,e), coastal upwelling appears in response to turning of the wind near the coast toward the west, probably in response to low barometric pressure effects related to solar heating of the adjacent land surface.

\section{DISCUSSION}

The Mediterranean Sea is not known for containing upwelling-dominated marine ecosystems. Nevertheless, several of the upwelling zones indicated in this study are substantial by world standards. For example, using previously published estimates of characteristic Ekman transport magnitudes (Parrish et al., 1983; Bakun and Parrish, 1990), one may calculate characteristic upward vertical velocities during the seasonal upwelling peak, averaged over a zone extending $50 \mathrm{~km}$ offshore (i.e., on a similar basis to the values produced in this study) for some of the well-known upwelling regions of the world. This would indicate that the values reached during late summer off southwestern Turkey, and during winter off the northeastern coast of the Gulf of Lyons are equal to those in the respective peak upwelling seasons off the Iberian Peninsula or off Cabo Frio, Brazil. In addition, they are about $50 \%$ of the seasonal peak intensity in the upwelling maximum core (Cape Mendicino) of the California Current, $45 \%$ that off north central Peru (Chimbote), $40 \%$ that off southern Peru (San Juan) or off Cap Blanc (in the Canary Current) and some $37 \%$ that off Lüderitz 
(in the Benguela Current) which is the most intense of the sustained eastern ocean coastal upwelling zones found on earth. (Of course, the most intense off large-scale ocean upwelling is that which occurs off northeastern Somalia during the Southwest Monsoon, but that system is quite a special case (Bakun et al., 1998).) However, one does not see (e.g., in satellite-sensed ocean color distributions) these inferred Mediterranean upwelling zones delineated as areas of particularly high surface chlorophyll. There are various factors that might at least partially account for this. Because of the relatively high latitude location of the northern parts of the Mediterranean (many people are surprised to realize that for example Venice, Italy, is actually further north than Halifax, Canada), a given intensity of offshore Ekman transport is accompanied by a much higher input of turbulent mixing energy by the wind than would be the case at lower latitude locations (Bakun, 1996). Thus, deep mixing will tend to inhibit development of blooms near the upwelling zone itself. (The congruities between the shapes of the spatial patterns of surface chlorophyl pigments and of rates of input of turbulent energy by the wind Agostini and Bakun (1999) are quite suggestive in this respect.) In both the cases of the Aegean and Gulf of Lyons upwellings, the nutrients that are upwelled into the surface layer are carried directly in the surface Ekman transport field toward zones of convergence, which also happen to be under the influence of fresher surface waters due to coastal runnoff, Black Sea inflow, major riverine lenses, etc. These "downstream" zones may be where a major portion of the upwelling-based production may actually result (Agostini and Bakun, 1999).

Off course, the nutrient input to the surface layers depends on the nutrient content of the waters at source of the upwelling. Certainly, the thermocline waters of the Mediterranean have much lower concentrations of dissolved nutrients than in eastern boundary currents, which contain rich sub-polar water masses being advected equator-ward within the thermoclines.

The work presented here does not attempt to present any convincing answers to such questions, but merely to provide a basis for posing them, and thereby to contribute to the progressive process of sorting out and elaborating the various factors influencing the biological productivity, species diversity, and resource sustainability of the Mediterranean Large Marine Ecosystem.

\section{ACKNOWLEDGEMENTS}

Funding support for this work was provided by the Mediterranean Action Plan of the United Nations Environment Programme (UNEP) and by the Marine Resources Service of the Food and Agriculture Organization of the United Nations (FAO)

\section{REFERENCES}

Agostini, V.N. and A. Bakun. - 1999. "Ocean Triads" in the Mediterranean Sea: Physical mechanisms potentially structuring reproductive habitat suitability. FAO, Rome.

Allen, J.S. - 1975. Coastal trapped waves in a stratified ocean. $J$. Phys. Oceanogr., 5: 300-325.

Arístegui, J., P.Tett, A. Hernández-Guerra, G. Basterretxea, M.F. Montero, K. Wild, P. Sangrá, S. Hernández-León, M. Cantón, J.A. García-Braun, M. Pacheco and E.D. Barton. - 1997. The influence of island-generated eddies on chlorophyll distribution: a study of mesoscale variation around Gran Canaria. Deep-Sea Res. I, 44: 71-96.

Bakun, A. - 1978. Guinea Current upwelling. Nature, 271: 147-150.

Bakun, A. - 1990. Global climate change and intensification of coastal ocean upwelling. Science, 247: 198-201.

Bakun, A. - 1996. Patterns in the Ocean: Ocean Processes and Marine Population Dynamics. University of California Sea Grant, San Diego, California, USA, in cooperation with Centro de Investigaciones Biológicas de Noroeste, La Paz, Baja California Sur, Mexico.

Bakun, A., and C.S. Nelson. - 1991. Wind stress curl in subtropical eastern boundary current regions. J. Phys. Oceanogr., 21: 1815-1834.

Bakun, A., and R.H. Parrish. - 1990. Comparative studies of coastal pelagic fish reproductive habitats: the Brazilian sardine (Sardinella aunta). J. Cons. Explor. Mer., 46: 269-283.

Bakun, A., and R.H. Parrish. - 1991. Comparative studies of coastal pelagic fish reproductive habitats: the anchovy (Engraulis anchoita) of the southwestern Atlantic. ICES J. mar. Sci., 48: $343-361$.

Bakun, A., D.R. McLain and F.V. Mayo. 1974. - The mean annual cycle of coastal upwelling off western North America as observed from surface measurements. Fish. Bull., U.S., 72: 843-844.

Bakun, A., C. Roy and S. Lluch-Cota. - 1998. Coastal upwelling and other processes regulating ecosystem productivity and fish production in the western Indian Ocean. In: E. Okemwa, M. Ntiba and K. Sherman, (eds.), Large Marine Ecosystems of the Indian Ocean: Assessment, Sustainability, and Management, pp. 103-141. Blackwell Science Inc. Malden, Massachusetts,

Breidenbach, J. - 1990. EOFs of pseudo-stress over the Indian Ocean (1977-85). Bull. Amer. Meteorol. Soc., 71: 1448-1454.

Crise, A. and G. Crispe. - 1998. The effect of seasonal forcings on the nutrients gradients in the Mediterranean Sea: a numerical approach. Rapp. Comm. int. Mer. Médit., 35: 112-113.

Cushing, D.H. - 1969. Upwelling and fish production. FAO Fish. Tech. Pap., 84.

Durand, M.-H., P. Cury, R. Mendelssohn, C. Roy, A. Bakun and D. Pauly (eds.). - 1998. Global Versus Local Changes in Upwelling Systems, ORSTOM Editions, Paris.

Ekman, V.W. - 1905. On the influence of the earth's rotation on ocean currents. Ark. Mat. Astron. Fys., 2: 1-55.

Gill, A.E. and A.J. Clarke. - 1974. Wind-induced upwelling, coastal currents, and sea level changes. Deep-Sea Res., 21: 325-345.

Goldenberg, S.B. and J.J. O'Brien - 1981. Time and space variability of tropical Pacific wind stress. Mon. Wea. Rev., 109: 1190-1207.

Mooers, C. and J.S. Allen. - 1973. Final Report of the Coastal Upwelling Ecosystems Analysis Summer 1973 Theoretical Workshop. School of Oceanography, Oregon State University, Corvallis, Oregon.

Nelson, C.S. -1977 . Wind stress and wind stress curl over the California Current. U.S. Dep. Commer. NOAA Tech. Rep., NMFS SSRF-714. 
Parrish, R.H., A. Bakun, D.M. Husby and C.S. Nelson. - 1983. Comparative climatology of selected environmental processes in relation to eastern boundary current pelagic fish reproduction. In: G.D. Sharp and J. Csirke, (eds.), Proceedings of the Expert Consultation to Examine Changes in Abundance and Species Composition of Neritic Fish Resources, pp. 731-778. FAO Fish. Rep., 291:

Roy, C. and R. Mendelssohn. - 1998. The development and the use of a climatic data set for CEOS using the COADS data set. In: M.-H. Durand, P. Cury, R. Mendelssohn, C. Roy, A. Bakun and D. Pauly (Eds.), Global Versus Local Changes in Upwelling Systems, pp. 27-44. ORSTOM Editions, Paris.

Servain, J. and D.M. Legler. - 1986. Empirical orthogonal function analysis of tropical Atlantic sea surface temperature and wind stress. J. Geophys. Res., 91: 14181-14191.

Slutz, R.J., S.J. Lubkeer, J.D Hiscox, S.D Woodruff, R.I.. Jenne, D.H. Joseph, P.M. Steurer and J.D. Elms. - 1985. Comprehensive Ocean-atmosphere Data Set; Release 1. NOAA Environ- mental Research Laboratories, Climate Research Program, Boulder, USA.

Smith, R.L. - 1968. Upwelling. Oceanogr. Mar. Biol. Ann. Rev., 6: 11-46.

Sverdrup, H.U. - 1938. On the process of upwelling. J. Mar. Res., 1: $155-164$.

Woodruff, S.D., R.J. Slutz, R.I. Jenne and P.M.Steurer. - 1987. A comprehensive ocean-atmosphere data set. Bull. Amer. Meteor. Soc., 68: 1239-1250.

Wooster, W.S., A. Bakun and D.R McLain. - 1976. The seasonal upwelling cycle along the eastern boundary of the North Atlantic, J. Mar. Res., 34: 131-141.

Yoshida, K. - 1967. Circulation in the eastern tropical oceans with special reference to upwelling and undercurrents. Japan. $J$. Geophys., 4: 1-75.

Scient. ed.: J. Font 